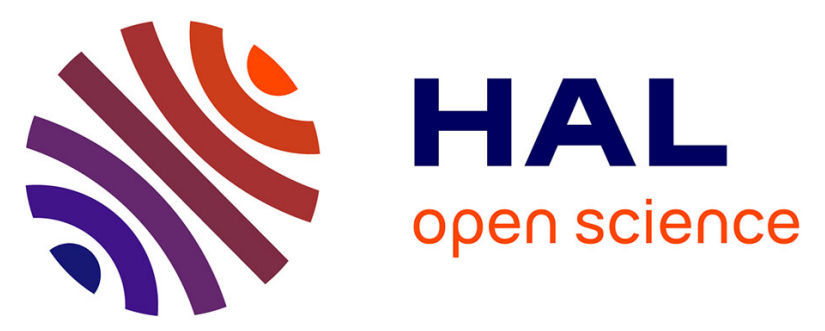

\title{
Geoarchaeology as a tool to understand ancient navigation in the northern Persian Gulf and the harbour history of Siraf
}

Majid Pourkerman, Nick Marriner, Christophe Morhange, Morteza Djamali, Giorgio Spada, Sedighe Amjadi, Matteo Vacchi, Hamid Lahijani, Mohammad Esmaeili Jelodar, Hossein Tofighian, et al.

\section{To cite this version:}

Majid Pourkerman, Nick Marriner, Christophe Morhange, Morteza Djamali, Giorgio Spada, et al.. Geoarchaeology as a tool to understand ancient navigation in the northern Persian Gulf and the harbour history of Siraf. Journal of Archaeological Science: Reports, 2020, 33, pp.102539. 10.1016/j.jasrep.2020.102539 . hal-02937277

\section{HAL Id: hal-02937277 \\ https://hal-amu.archives-ouvertes.fr/hal-02937277}

Submitted on 12 Aug 2021

HAL is a multi-disciplinary open access archive for the deposit and dissemination of scientific research documents, whether they are published or not. The documents may come from teaching and research institutions in France or abroad, or from public or private research centers.
L'archive ouverte pluridisciplinaire HAL, est destinée au dépôt et à la diffusion de documents scientifiques de niveau recherche, publiés ou non, émanant des établissements d'enseignement et de recherche français ou étrangers, des laboratoires publics ou privés.

\section{(1) (1) $\$$}

Distributed under a Creative Commons Attribution - NonCommercial - NoDerivatives 44.0 


\title{
Geoarchaeology as a tool to understand ancient navigation in the northern Persian Gulf and the harbour history of Siraf
}

\author{
Majid Pourkerman $^{\mathrm{a}, \mathrm{g}}$, Nick Marriner ${ }^{\mathrm{b}, *}$, Christophe Morhange ${ }^{\mathrm{a}}$, Morteza Djamali ${ }^{\mathrm{c}, \mathrm{g}}$, \\ Giorgio Spada $^{\mathrm{d}}$, Sedighe Amjadi ${ }^{\mathrm{e}, \mathrm{g}}$, Matteo Vacchi ${ }^{\mathrm{f}}$, Hamid Lahijani ${ }^{\text {, }}$, \\ Mohammad Esmaeili Jelodar ${ }^{\mathrm{h}}$, Hossein Tofighian ${ }^{\mathrm{i}}$, Abdolmajid Naderi Beni ${ }^{\mathrm{g}}$ \\ ${ }^{a}$ Aix Marseille Univ, CNRS, IRD, INRAE, Coll France, CEREGE, Aix-en-Provence, France \\ ${ }^{\mathrm{b}}$ CNRS, ThéMA UMR 6049, Université de Bourgogne Franche-Comté, 32 rue Mégevand, Besançon Cedex 25030, France \\ ${ }^{\mathrm{c}}$ Institut Méditerranéen de Biodiversité et d'Ecologie (IMBE/UMR7263), Aix Marseille Université, Avignon Université, CNRS, IRD, IMBE, Technopôle Arbois-Méditerranée, \\ Bât. Villemin, BP 80, F-13545 Aix-en-Provence cedex 04, France \\ d Dipartimento di Scienze Pure e Applicate, Urbino University "Carlo Bo", Urbino, Italy \\ e Department of Geology, Faculty of Sciences, Ferdowsi University of Mashhad, Mashhad, Iran \\ ${ }^{\mathrm{f}}$ Dipartimento di Scienze Della Terra, Università di Pisa, 56126 Pisa, Italy \\ ${ }^{g}$ INIOAS (Iranian National Institute for Oceanography and Atmospheric Sciences), No. 3, Etemad Zadeh St., Fatemi Ave., Tehran, Iran \\ ${ }^{h}$ Department of Archaeology, Faculty of Letters and Humanities, University of Tehran, 1417614418 Tehran, Iran \\ ${ }^{\mathrm{i}}$ Institute of Archaeology of Iran, Underwater Archaeology Department, Archaeology Research Centre, Si-e Tir St, Imam Khomeini St, Tehran, Iran
}

\begin{abstract}
A B S T R A C T
Historical texts and archaeological studies attest to the maritime and trade importance of the Persian Gulf since the Sassanid Empires. Nonetheless, there is a paucity of data regarding ancient navigation and the reasons for a shift in $\mathrm{m}$ aritim etrade from the western (e.g. Shatt-al-Arab) to eastern (Siraf) Persian Gulf by the Abbasid dynasty. For som e scholars, Siraf was occupied between 360 and 977 CE, after which time an earthquake entrained the dem ise of the city. However, it is unclear when Siraf was founded and how natural navigation conditions changed for ocean-going vessels in harbours of the NW Persian Gulf. To address this knowledge gap, we here present new geoarchaeological data from Siraf. Two anthropogenic facies were detected in drilled cores. They suggest that Siraf dates back to 2 BC-317 CE. After a hiatus, a second occupation phase began during the reign of Shapur II. Relative Sea-Level (RSL) fluctuations, climate change and Persian Gulf bathymetry all affected the possible nautical accessibility of this ancient Persian harbour. A fall in RSL, leading to a shortening of navigable water columns and amplified summer-time Shamal wind from $550 \mathrm{CE}$ onwards possibly led to a loss in the importance of Shatt-al-Arab and other ports in the western Persian Gulf. It appears to have made Siraf the best alternative for seafarers. According to the wind regimes, the best time for arrival and departure from Siraf was August and October, respectively. RSL rise and increasing coastal erosion during the winter-time Shamal winds led to the degradation of harbour potentialities and was possibly at the origin of economic decline and poorly adapted harbour works at Siraf during a 150-year period between 850 and 1000 CE.
\end{abstract}

\section{Introduction}

Although the history of maritime trade in the Persian Gulf dates back to the 3rd century BCE (Caspers, 1971), maritime trade did not thrive until the 8th century CE onwards. During the 9th to 10th centuries $\mathrm{AD}$, historians such as Tabari, al-Istakhri, Ibn Hawqal, al-Mas'udi (Tabari, 1987, al-Istakhri 1870, Ibn Hawqal 1965, al-Mas'udi, 1962) describe Siraf as the most important port of the Persian Gulf. Much of our understanding of Siraf's archaeological record is attributed to the work of Stiffe (1895); Whitehouse (1968)); Whitehouse (1969, 1970); Whitehouse (1971) and Whitehouse and Williamson (1973). Since these studies, however, just a handful of investigations and excavations have taken place in Siraf (Khakzad and Trakadas, 2014; Pashazanous et al., 2014; Khakzad et al., 2015). Numerous knowledge gaps remain regarding the rise and fall of Siraf as a key port settlement.

Geoarchaeological studies based upon geoscience tools have the potential to answer key archaeological questions about ancient sites (Marriner and Morhange, 2007; Marriner et al., 2005, 2010, 2017).

\footnotetext{
* Corresponding author.

E-mail address: nick.marriner@univ-fcomte.fr (N. Marriner).
} 
Geoarchaeological studies in coastal areas can shed light on humanenvironment interactions using a multidisciplinary framework that marries archaeology, geomorphology, palaeoclimatology, relative sealevel changes, biology and geochemistry (Marriner and Morhange, 2007; Ferrario, et al., 2015). However, very few geoarchaeological studies have been undertaken on medieval Mediterranean harbours (Marriner et al., 2006; Morhange and Marriner, 2010; Goiran et al., 2014, Vacchi et al., 2020). In a similar vein, no comprehensive geoarchaeological studies have been conducted on ancient harbours of the Persian Gulf from this period (Pourkerman et al., 2018).

Apologus, formerly known as Ubulla, was the most important port in the northwest Persian Gulf during Sassanid to Abbasid periods (Le Strange, 1905). The port was located at the mouth of the Shatt-al-Arab River. Basra (Abbasid capital) was supported by Ubulla port. The trade seasons in Basra were mediated by the rhythm of the Indian monsoon. The ships and goods arrived in July and vessels had to depart before the onset of Indian Ocean winds in October (Potter, 2009). By the early centuries of Islam, maritime trade in Ubulla declined. There was a successful transition of the most important harbours from Ubulla (northwest) to Siraf (center) (Sheriff, 1987).

The aim of this paper is to investigate the impacts of RSL and climate changes on ancient navigation in the Persian Gulf, including the displacement of important harbours from the northwest to the central part of the Gulf. In this study, we also analyze Siraf's infrastructure and its coastal morphology in order to shed light on its evolution during mediaeval times.

\section{Geological and geomorphological settings}

The present morphological features of the Persian Gulf are the result of Paleozoic to Quaternary orogeny (Kashfi, 1976; Alavi, 1994, 2004; Sharland et al., 2004). The main axis of the asymmetric Persian Gulf follows the Zagros folding system (Fig. 1). The axis has generated two main synclines in the western and central northern half of the Gulf, named the western and central basins (Seibold and Vollbrecht, 1969) (Fig. 1). The basins are connected through transverse shoal between two synclinal areas reflected to uplift along the northward prolongation of the Qatar Arc (Ras-e-Motaf). In the central basin, the axis is situated close to the Iranian coast, in the Kangan area. This section of the Gulf is generally steeper and deeper than the western basin and contains huge folds with steeply-dipping flanks in the hinterland. These features have created narrow coastal plains associated with numerous ephemeral streams, estuaries and a steep coastal bathymetry close to the shoreline (Fig. 1) (Purser and Seibold, 1973).

Marl (Kazhdomi, Mishan), sandstone with gypsum and marl (Aghajari) and conglomerates with calcareous sandstone (Bakhtiyari) are the main Cretaceous-Pliocene formations that folded in the last Zagros orogenic movement during Miocene/Pliocene times. Erosion has generated a scarp-and-valley landscape (Fig. 2). Siraf is flanked by calcareous sandstone with interlayers of conglomerate rock to the north, into which several wells and graves have been cut (Wilkinson, 1974).

The Persian Gulf coastal morphology is influenced by plate and salt tectonic regimes. Three morphological zones are recognizable: (i) Zone I: gently sloping marshland coasts with permanent rivers (Shat-al-Arab, Zohre, Hilla and Mand) and several ephemeral rivers with high sediment supply to the shallow coastal zone; (ii) Zone II diapiric uplifting coasts with salt domes; and (iii) Zone III rocky coasts with steep coastal slopes (Fig. 1). The ancient city of Siraf is located in zone III, in the central basin. It is characterized by a narrow coastal plain and numerous short fluvial systems, including three ephemeral rivers (Figs. 2 and 3) (Whitehouse, 1968).

\section{Palaeoenvironments and salt tectonics}

During the early Holocene inundation of the Persian Gulf (10.5-9.5 kyr BP) (Lambeck, 1996), the mean latitudinal position of the summer ITCZ advanced rapidly northwards. A RSL highstand of +2 m occurred around 7.1-6.89 kyr B.P. (Lambeck, 1996; Lokier et al., 2015). At this time, monsoon rains migrated further north than at present, over the Persian Gulf and Iran (Fleitmann et al., 2003; Djamali et al., 2010. Enhanced precipitation over northern Oman and the central part of the Persian Gulf, resulted from the more northerly monsoon position (Fleitmann and Matter, 2009). It would have been conducive to heightened erosion of continental zones and increased sediment supply/progradation to/of coastal areas. A comparable situation has been observed along the coastline of the Nile Delta, which, after a phase of deltaic growth and progradation has become more vulnerable to coastal erosion during the past 4000 years, due to falling sediment supply Marriner et al., 2013). For instance, in the Bay of Abukir, on the western flank of the delta, the ancient cities of Eastern Canopus and Herakleion today lie 5-7 m below current mean sea level (Flaux et al., 2017).

Furthermore, it is possible that inundation of the Persian Gulf led to increased vertical stress of the basin floor that could have reactivated regional salt domes. The salt domes lie in the Hormuz formation and were active before the Zagros folding. The domes were reactivated by subsidence resulting from Zagros tectonic events (Jahani et al., 2007). The distribution of the salt domes is depicted in Fig. 1. Deformation of a narrow zone along the Persian Gulf littoral has led to a concentration of domes along the present coast that are classified as active salt domes (zone II) (Jahani et al., 2007). These coastal salt domes could have been reactivated following the displacement of salt to the edge of the area due to basin subsidence resulting from increased vertical stress (Wood et al., 2012).

\section{Meteorological and physical oceanography}

The main weather phenomenon in the Persian Gulf is a strong northwesterly Shamal wind that occurs during summer and winter (Perrone, 1979). The summer Shamal winds result from interaction between summer monsoon low-pressure systems over NW India, that extend to the W to SE parts of the Gulf, and stationary high-pressure systems over the Mediterranean with a ridge extending SE towards the NW of the Persian Gulf (Bartlett, 2004). Winter Shamal wind over the north of the Persian Gulf is affected by cold air carried into the region by quasi-stationary Siberian high pressure in the east (Crook, 2009). It is usually interrupted by a frontal system that is created in the east of the Mediterranean Sea and tracks to the southeast following the polar front jet. The frontal system moves toward the Persian Gulf with the polar front jet behind and sub-tropical jet ahead of the frontal system converge, strengthening the system and generating strong wind at the front. The NW wind is strong during its passage over the northern Persian Gulf and it reaches five times its initial surface speed (15-20 m/ s) in the central part of the Gulf (Thoppil and Hogan, 2010). The intensity of the Shamal wind is enhanced by the funnel-like structure of the Zagros Mountain along the Iranian coast (Giannakopoulou and Toumi, 2012). The other weather system that affects the summer-time Shamal wind is the Indian Ocean Dipole (IOD). A positive IOD leads to decreased summer precipitation in the Persian Gulf and increasing duration and intensity of the summer Shamal wind (Al Senafi and Anis, 2015). The winter Shamal brings cold and dry air that leads to falling temperatures and evaporation (Thoppil and Hogan, 2010). The wintertime Shamal wind, that blows during January and February, creates the highest waves in the middle part (central basin) of the Persian Gulf, whereas, the summer-time Shamal (June and July) influences the northwestern part of the Persian Gulf, especially at Shatt-al-Arab and Ras-e-Motaf. The intensity of the Shamal wind is attenuated following the summertime Shamal and it reaches its minimum during September and October (Kamranzad, 2018).

Evaporation and freshwater inputs create differences in water densities between the northern and southern parts of the Persian Gulf. This 

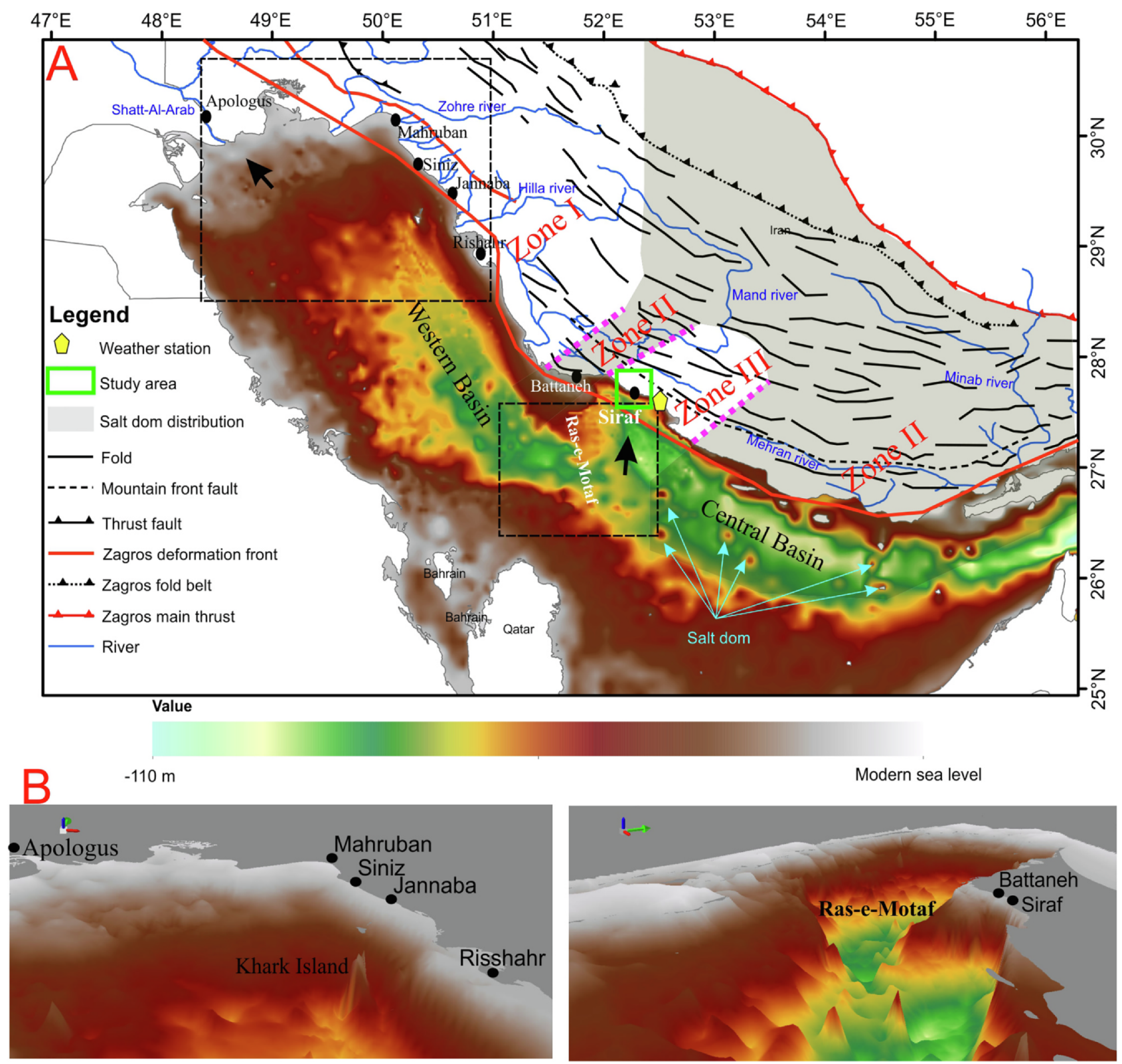

Fig. 1. A) General morphology of the Persian Gulf with the location of some of its ancient harbours and distribution of the salt domes in southern Iran (Arian and Noroozpour, 2015) (B) 3D coastal morphology of the harbours. The black arrows denote the positions of the Shatt-al-Arab delta and the Siraf coastline. The bathymetry values are also valid for $\mathrm{B}$.

feature leads to marine water inflow via the Straits of Hormuz, before flowing in a NW direction along the Iranian coast (Reynolds, 1993). It subsequently splits into two branches: (i) one branch continues on a NW path, while (ii) the second veers offshore and joins the returning southeastern flow. The Shamal wind intensifies the outflowing branch (Thoppil and Hogan; 2010). Water circulation and the distribution of basin wave power is represented in Fig. 5. The highest wave energy, with an anti-clockwise whirlpool under storm conditions, occurs in the Ras-e-Motaf. This part of the Persian Gulf is known as Iran's "Bermuda triangle" and it has been an area of numerous shipping accidents (Kamranzad et al., 2013).

The Persian Gulf has semi-diurnal and diurnal tides with an oscillation period between 21.6 and $27 \mathrm{~h}$ (Defant, 1961). The tidal currents are mediated by Persian Gulf water circulation and bathymetry. In the Bandar-e Abbas (Straits of Hormuz), because of water exchanges between the Persian Gulf and the Oman Sea, tidal currents are faster and Mean Higher High Water (MHHW) is higher than elsewhere in the Gulf
(Table 1). Tidal currents are also strong in shallow waters (Pous et al., 2012). MHHW in the Shatt-al-Arab estuary is $+3 \mathrm{~m}$ and MLLW is $0.4 \mathrm{~m}$.

\section{The ancient urban fabric of Siraf}

The port of Siraf was a point of connection between the Persian Gulf and the Far East. Merchants imported spices, silk and other luxury goods, and exported pearls, Arabian-produced frankincense and other precious resins (Whitehouse and Williamson, 1973). Our knowledge of the ancient urban fabric of Siraf is limited because of sparse excavations and the loss of ancient remains due to natural and anthropogenic activities. In this study, we focus on the work of Whitehouse, 1968, 1969, 1970, 1971, who performed a comprehensive investigation of medieval Siraf, producing valuable data and maps. The buildings generally manifest a NE-SW orientation except the great mosque (for religious reasons) and benefit from shallow wells (Fig. 3).

The archaeological excavation by Whitehouse (1968) in the 


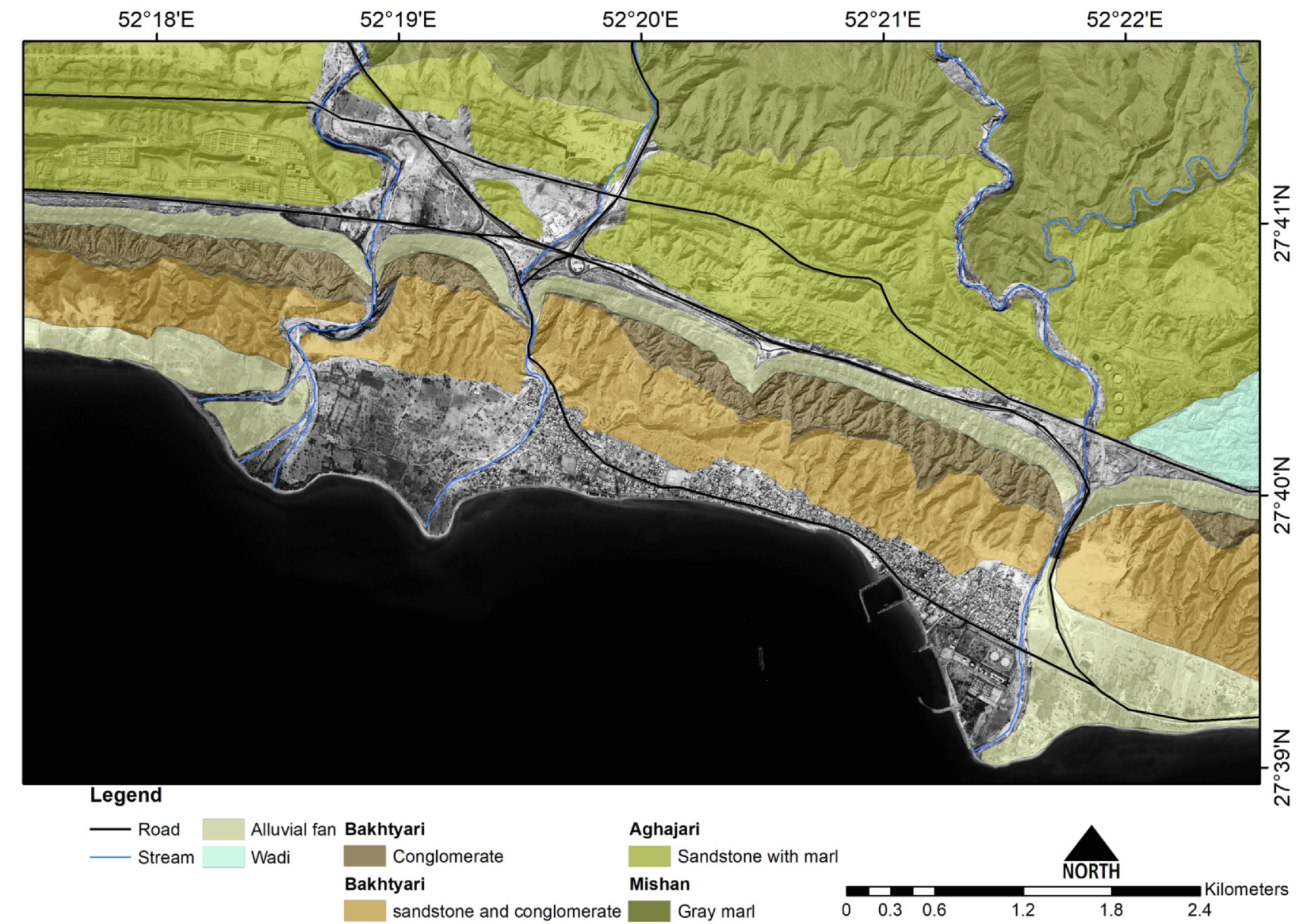

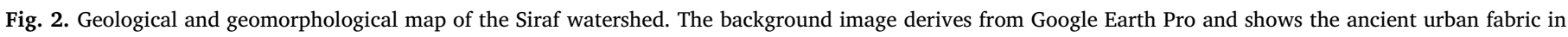
July 2018. Most of the historic sectors have been destroyed with the exception of some coastal quarters at risk from coastal erosion.

northwest area of the great mosque (section B) (Fig. 3) elucidated three important occupation layers. The earliest occupation (Period 1) contained undisturbed beach sand, located $1 \mathrm{~m}$ above current sea level. It lies beneath mixed sand and clay with a horizon showing abundant Sassanid-Islamic pottery (before cal. $825 \mathrm{CE}$ ). Period 2 contains four generations of buildings that are covered by rubble from the collapse of large buildings. The approximate age of period 2 is between $825 \pm 25$ to $977 \pm 78$ AD. Finally, period 3, dating to the late 11th century CE onwards, comprises a poor agricultural soil.

Construction materials were selected as a function of accessibility to natural resources. Bakhtiray conglomerate was exploited as a source of rubble and the Aghajari formation was quarried for gypsum. These materials were broadly used for building constructions and city protection structures. Cooked gypsum was employed as cement and for interior-exterior facing. The cooked gypsum absorbs humidity from the air and would have helped to decrease inside temperatures during warm and humid seasons. The use of rubble stone materials with gypsum mortar, in addition to gypsum as an interior decorative material, was very common under Sassanian rule (Huff, 1986).

\section{Methods and data acquisition}

The main parts of the coastal zone in the medieval sector of Siraf are covered by gravel. The gravel accumulations result from the destruction of archaeological remains by coastal erosion (Pourkerman et al., 2018). A continuous series of 3-m cores was drilled using a vibracore in the SE part of the medieval Bazaar at $17 \mathrm{~cm}$ above current Mean Sea Level (MSL) (Fig. 3). The core tubes were immediately transported to the laboratory for nondestructive magnetic susceptibility analysis (MS).
The coring site was levelled using a theodolite and benchmarked relative to current sea level. All depths are relative to present mean sea level. A $2.4 \mathrm{~m}$ outcrop section was logged at a site called the "Potter's Quarter" (Fig. 3) where a whole sedimentary sequence was observed beneath an ancient building.

Before subsampling, magnetic susceptibility was measured using a Bartington MS2C 100-mm diameter loop sensor with an MS2 meter. Magnetic susceptibility was measured every $2 \mathrm{~cm}$ (Delile et al., 2014), in order to probe human impacts on the sedimentary properties.

High-resolution sampling was undertaken on each of the cores (44 sub-samples over $3 \mathrm{~m}$ ). Each sample was split into two subsamples for grain-size, organic matter and carbonate-content analyses. Wet sieving was employed to separate the $>2 \mathrm{~mm}$ and $<63 \mu \mathrm{m}$ fractions. Dry sieving was performed for the sand granulometry and a laser grain-size analyzer (Horiba La $950 \mathrm{E}$ ) was used for the silt/clay fractions. The sediments were classified and plotted on a ternary diagram using the methodology outlined by Folk (1954, 1980). Organic Matter (OM) and carbonate content were measured using Loss-On-Ignition (LOI) at $550{ }^{\circ} \mathrm{C}$ and $950{ }^{\circ} \mathrm{C}$ (Heiri et al., 2001). The mean grain size was calculated using Folk and Ward (1957). The chronological data are based on the correlation of core facies with archaeological excavation data from Siraf. Juvenile marine shells contained in the anthropogenic facies were used for radiocarbon dating. The ${ }^{14} \mathrm{C}$ data were calibrated using Calib version 7.1.0 online version (http://calib.org) and a standard Persian Gulf marine reservoir age (Southon et al., 2002) (Table 2). Historic wind directions and durations were obtained from the database of the Iranian Meteorological Office (http://irimo.ir). Bathymetric maps and 3D models of the seafloor were created based on hydrological maps of the Iranian National Cartographic Center and international 

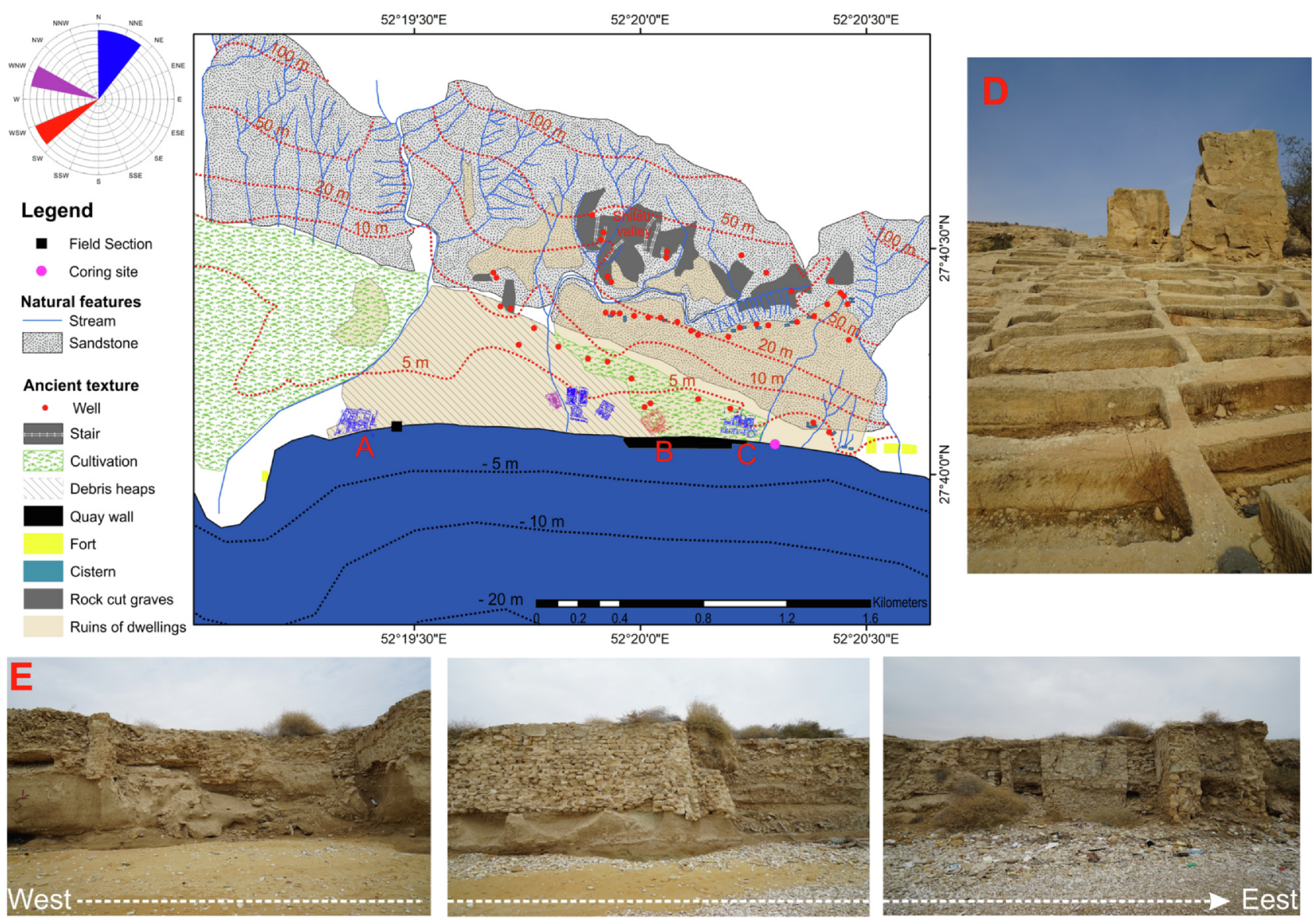

Fig. 3. Map of Medieval Siraf, with the location and orientation of its buildings (Whitehouse, 1968). The rose diagram shows that the ancient buildings trend towards the north. The most important waterfront remains are A) the Potter's Quarter, B) the great mosque and C) the Bazaar. The different colours represent different orientations. D) Rock cut grave at Shilau valley and E) water front remains that exposed severe coastal erosion (Pourkerman et al., 2018).

chart series published by the United Kingdom hydrographic office in scales 1:100,000 for the Persian Gulf and 1:20,000 for the Shatt-al-Arab pro-delta area.

The RSL curve was obtained by a Glacial Isostatic Adjustment (GIA) simulation in which we adopted model ICE-6G (VM5a) of Peltier et al. (2012) and Peltier et al. (2015). The simulation used the ICE-6G (VM5a) model through the program SELEN4 (Spada and Melini, 2019). SELEN4 solves the Sea-Level Equation by taking into account the horizontal migration of shorelines, for the transition from grounded to floating ice and for the effects of rotational feedbacks on sea level. The Sea-Level Equation was solved using a pseudo-spectral approach with a spatial resolution corresponding to the maximum harmonic degree $\operatorname{lmax}=256$, on a grid with a spacing of $\sim 40 \mathrm{~km}$.

\section{Results}

\subsection{Present-day wind and wave regimes}

The winter and summer-time Shamal winds have a WNW direction. The wind speed in wet seasons (Oct-Mar) is stronger than in dry seasons, although wind duration in the dry seasons (Apr-Sep) is longer (Table 3, Fig. 4). Secondary wind directions in the dry and wet seasons blow from the $\mathrm{S}$ and NW respectively. The NW wind direction is less frequent and blows in April, October and November, for around 83 days with an average speed of $14 \mathrm{~m} / \mathrm{s}$. It is as strong as the WNW Shamal wind. The $\mathrm{S}$ wind is weaker than the dominant wind direction and it blows from July to September for 118 days with an average speed of $9.75 \mathrm{~m} / \mathrm{s}$. The $S$ wind is the dominant wind in August.

Table 1

Geomorphological zonation and tidal levels at different sites from the Strait of Hormuz to Shatt-al-Arab.

\begin{tabular}{|c|c|c|c|c|c|c|c|}
\hline \multirow[t]{2}{*}{ Place } & \multirow[t]{2}{*}{ Lat $\mathrm{N}$} & \multirow[t]{2}{*}{ Long E } & \multicolumn{4}{|c|}{ Height in meters above datum } & \multirow[t]{2}{*}{ Class } \\
\hline & & & MHHW & MLHW & MHLW & MLLW & \\
\hline Bandar-e Abbas & $29^{\circ} 22^{\prime}$ & $56^{\circ} 17^{\prime}$ & 3.4 & 2.6 & 1.4 & 0.7 & Zone II \\
\hline Asaluyeh ${ }^{*}$ & $27^{\circ} 28^{\prime}$ & $52^{\circ} 37^{\prime}$ & 1.6 & 1.5 & 0.7 & 0.3 & Zone III \\
\hline Bandar-e Bushehr & $28^{\circ} 54^{\prime}$ & $50^{\circ} 45^{\prime}$ & 1.9 & 1.3 & 1.1 & 0.5 & Zone I \\
\hline Bandar-e Ganaveh & $29^{\circ} 34^{\prime}$ & $50^{\circ} 31^{\prime}$ & 2.2 & 1.5 & 1.3 & 0.6 & Zone I \\
\hline Imam Hassan & $29^{\circ} 50^{\prime}$ & $50^{\circ} 15^{\prime}$ & 2.4 & 1.7 & 1.3 & 0.6 & Zone I \\
\hline Shatt-al-Arab & $29^{\circ} 50^{\prime}$ & $48^{\circ} 43^{\prime}$ & 3.0 & 2.4 & 1.3 & 0.4 & Zone I \\
\hline
\end{tabular}

* Asaluyeh is the nearest tide gauge station to the site of ancient Siraf. 
Table 2

Calibrated radiocarbon ages for two anthropogenic facies.

\begin{tabular}{|c|c|c|c|c|c|c|}
\hline \multirow[t]{2}{*}{ ID } & \multirow[t]{2}{*}{ Depth } & \multirow[t]{2}{*}{ Radiocarbon Age } & \multicolumn{3}{|l|}{ Calibration } & \multirow[t]{2}{*}{ Significance } \\
\hline & & & 1 sigma & Significance & 2 sigma & \\
\hline Siraf 1 & $177 \mathrm{~cm}$ & $2305 \pm 67$ & cal AD 223-404 & 68.3 & cal AD 113-478 & 95.4 \\
\hline Siraf 2 & $235 \mathrm{~cm}$ & $2385 \pm 101$ & cal AD 91-342 & 68.3 & cal BC 44-AD 459 & 95.4 \\
\hline
\end{tabular}

\subsection{Fresh-water management system}

According to field observations, the city is located in a coastal desert with average precipitation of $13.2 \mathrm{~mm} / \mathrm{yr}$. Flash flooding takes place during winter and autumn; at the time of writing, the most recent example dated to the 23rd March 2020. The city's fresh water was supplied by harnessing and storing rainfall via numerous wells and cisterns on the hills overlooking Siraf, and stocked in alluvial sediments overlooking the ancient settlement (Fig. 3). The wells, excavated into the hills, are protected from sediment influx by manmade rocky stairs, plastered mortared rubble and a $5-10 \mathrm{~cm}$ protuberance. Further features of the wells are shallow rills to direct water to the well mouth. Pronounced water erosion in the upstream Shilau valley, with several outlet tunnels, was observed on the downside of the wells. Shallow wells (upper present sea-level) and cisterns are reported for medieval Siraf, for both cultivation and domestic purposes (Whitehouse, 1968, 1969, 1971) (Fig. 6).

\subsection{Paleoenvironmental analysis}

\subsubsection{Upper shore facies}

The stratigraphic units were bounded between two upper shore facies (US1 and US3 at the base and top, respectively). Another upper shore facies was also logged at 72-82 cm (US2). The US1 transitioned between slightly gravelly sand $((\mathrm{g}) \mathrm{S}$ ) with bivalve shells and juvenile shells of Veneridae to gravelly sand ( $\mathrm{g}$ S) with abundant shell debris. An increase in OM is observed between 284 and $267 \mathrm{~cm}$; OM decreases with rising carbonate and sediment grain size. MS in the US1 is also represented decrease trend from base to top $\left(1.4 \times 10^{-4} \mathrm{SI}\right.$ to $\left.4.06 \times 10^{-5} \mathrm{SI}\right)$. The facies changes in US1 represent rising energy conditions due to the transition in sedimentary environments from lower shoreface to upper shoreface following a sea-water regression. US2 is made of gravelly sand with fine shell debris and sand. US2 sediments comprise medium to fine sands. Gravel decreases dramatically from base to top concurrent with increasing fine sand $((g) S)$. An inverse trend is observed for MS $\left(2.5 \times 10^{-5} \mathrm{SI}\right.$ to $\left.5.06 \times 10^{-5} \mathrm{SI}\right)$ (Fig. 7). The increase of carbonate content in this facies is related to increasing shell debris. The positive correlation between MS and carbonate content results from the impact of winnowing on magnet mineral residuals and bioclast debris reworking. US3 transitions from gravelly sand to slightly gravelly sand. The mean sediment grain size decreases upwards. The main difference between the facies US2 and US3 is the absence of bivalve shells at US2. It is suggested that US2 is more under the influence of wind processes than coastal action.

The sediment outcrop exposed in the Potter's Quarter shows a shoreface facies between 95 and $200 \mathrm{~cm}$ above present-day sea level. It contains light brown shelly sand with ceramics at the top, with alluvial facies at the base. The alluvial facies comprises fine sand and silt with interlayers of cobbles in a sandy silt matrix. This facies attests to flooding events during heavy precipitation and debris flows resulting from flashflood events. A narrow coastal plain void of any significant vegetation cover increased the risk of flooding at Siraf. The thickness of the outcrop facies decreases from west to east of the Potter's Quarter section (Fig. 3E).

\subsubsection{Unit B (anthropogenic facies)}

7.3.2.1. Anthropogenic facies. Two important anthropogenic facies (A1 and A2) are recorded at 203-240 and $149-178 \mathrm{~cm}$. According to radiocarbon analysis, A1 is dated to $44 \mathrm{cal}$. BC $-425 \mathrm{cal}$. AD; it comprises a very compacted facies, with iron and ceramic fragments. A1 is located above US1 and the facies comprises $30-89 \%$ gravel and the mean grain size is between 1 to -1.1 phi. The MS data manifests three peaks in this unit, with a maximum of $1.03 \times 10^{-3}$ (SI) and an average of $7 \times 10^{-4}(\mathrm{SI})$. Meanwhile, we did not observe upper shore facies above $\mathrm{A} 1$ and beneath $\mathrm{A} 2$, suggesting the resumption of anthropogenic activities shortly after the RSL fall (Fig. 8). A2 contained coarser sediments ( -0.6 to -1.11 phi) with $65-90 \%$ of the sediments comprising gravels. A sample from this second anthropogenic facies yielded a calibrated radiocarbon age of 113-477 cal. AD. Two MS peaks of $1.53 \times 10^{-3}$ and $1.21 \times 10^{-3}$ are logged in this unit, with an average MS of $6.6 \times 10^{-4}$ SI (Fig. 7).

7.3.2.2. Erosion and accretion facies. The marine facies above A1 is generally made-up of sandy gravel sediments. The gravel abundance changed from $70 \%$ to $46 \%$, from base to top. Furthermore, MS decreased from base to top $\left(6.78 \times 10^{-4} \mathrm{SI}\right.$ to $\left.4.63 \times 10^{-5} \mathrm{SI}\right)$ consistent with a decreasing gravel fraction. Sediment texture changed to gravelly sand with significant decline in carbonate that overlies the accretion facies. Fining upward in the accretion zone is consistent with a fall in energy dynamics. The same trend is observed for $\mathrm{A} 2$, the main difference being that the erosion and accretion facies above it are thicker than A1. It could suggest that RSL oscillations in the central part of the Persian Gulf happened over longer periods (Fig. 8). In other words, RSL oscillations in the Persian Gulf were controlled by hydrostatic pressure changes over the central basin floor resulting from global sea-level fluctuations (Pourkerman et al., 2020). The thickness of erosion-accretion facies decrease upwards and end at US2. The facies are recognized by changes in sedimentary structures and manifest reworked manmade material in the stratigraphic column. The sediment grain size in the erosional facies is upward fining. $46-75 \%$ of the sediment properties are created by $>2 \mathrm{~mm}$ portions and the sediment texture is sandy gravel. Upwardly decreasing magnetic susceptibility values $\left(1.2 \times 10^{-4} \mathrm{SI}\right.$ and $\left.1.6 \times 10^{-4} \mathrm{SI}\right)$ over the anthropogenic facies represents a rapid rise in RSL and increasing marine-sediment

Table 3

17-year wind speed $(\mathrm{m} / \mathrm{s})$ and duration averages, categorized by month and by wet and dry seasons.

\begin{tabular}{lllllllllllllll}
\hline Month & \multicolumn{10}{c}{ Season } & \multicolumn{1}{c}{} \\
\hline & Jan & Feb & Mar & Apr & May & Jun & Jul & Aug & Sep & Oct & Dec & Nov & Wet & Dry \\
\hline Speed $\mathrm{m} / \mathrm{s}$ & 10.8 & 13.5 & 13.4 & 12.8 & 14.5 & 12.6 & 11 & 10.5 & 9.25 & 9.5 & 11.8 & 10.8 & 12.5 & 11.3 \\
Days (number) & 76 & 117 & 57 & 59 & 174 & 56 & 88 & 16 & 63 & 76 & 86 & 120 & 331.7 & 473 \\
\hline
\end{tabular}




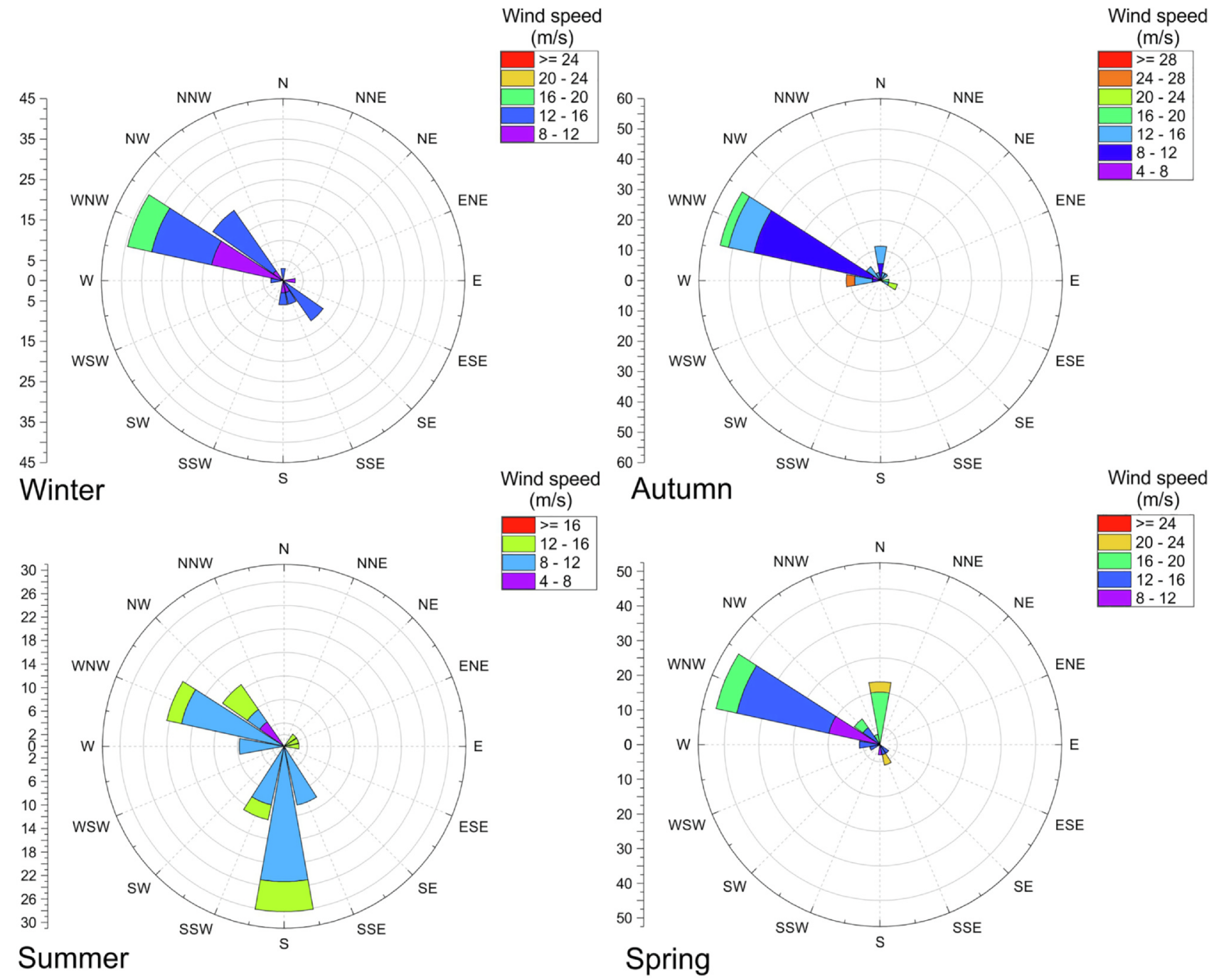

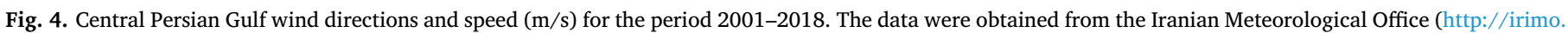
ir).

deposition. US2 is covered by accretion facies after a rising in RSL (950-1230 CE).

Gravel accumulations at $0-13 \mathrm{~cm}$ and $16-27 \mathrm{~cm}$ resulted from a decrease in the rate of sand deposition and an increase of cumulative bed-load transport during storm events (Lisle, 1989). Therefore, the gravel portions were mixed with fine to very fine sand. These erosional facies were influenced by storm action rather than RSL oscillations.

\section{Discussion}

\subsection{Impact of RSL and Shamal winds on the geography of important} harbour locations

RSL in the central basin is controlled by global sea-level rise and salt tectonics (Pourkerman et al., 2020). The modeled relative sea level (RSL) curve for Siraf suggests that RSL was higher than present during the late Parthian and early Sassanid (Fig. 8) periods. Meanwhile, a rapid RSL fall started at $\sim 50 \mathrm{cal}$. BC and with a lowstand between 50 and $150 \mathrm{CE}$. The chronological data suggest that the first anthropogenic activity in the coastal area of Siraf is recorded during the late Parthian to the first Sassanid empires (44 BC-452 CE). After a short time, marine facies overly A1 following a RSL rise. Seafaring in the Persian Gulf was vital to Persia's commercial and maritime activities during the Sassanian period. Rising RSL created opportunities to extend maritime trade along the northwest coast. As a result, several ports were founded between 226 and 241 CE (Vosougi and Sefatgo, 2016).

Flourishing seafaring and maritime trade in the Persian Gulf during the Sassanid Empire prompted Shapur II to build coastal defenses along the Siraf coastline to counter the threat of Arab raids (Whitehouse and Williamson, 1973). Subsequently, the most important harbours during the Sassanian dynasty were built in the northwest part of the Persian Gulf because of their vicinity to the capital, Istakhr. Apologus, located on the river Shatt-al-Arab, became the main port for Sassanian trade (Le Strange, 1905).

The radiocarbon chronology confirms that the facies A2 elucidated in our studied core can be attributed to the early Sassanian period (113 CE-477 CE), when Siraf was erected as a military base in order to protect the maritime trade activites. The unit A2 was concurrent with a second RSL fall. The thicker marine facies over A2 represents slower RSL changes between 450 and 750 cal. AD. RSL in the Persian Gulf experienced another lowstand with the onset of summer Shamal winds during the late Umayyad to mid Abbasid dynasties, around 700 to $950 \mathrm{cal}$. AD. It led to an increase in navigation risk, such as sinking in shallow water, for ocean-going ships from Janaba (Ganaveh) to Basra (Shatt-al-Arab) (Fig. 1). From an environmental perspective, the last RSL fall coincided with the development of Siraf harbour from 850 to 1000 CE (Fig. 8).

The demise of the Umayyad dynasty and the rise of the Abbasid 


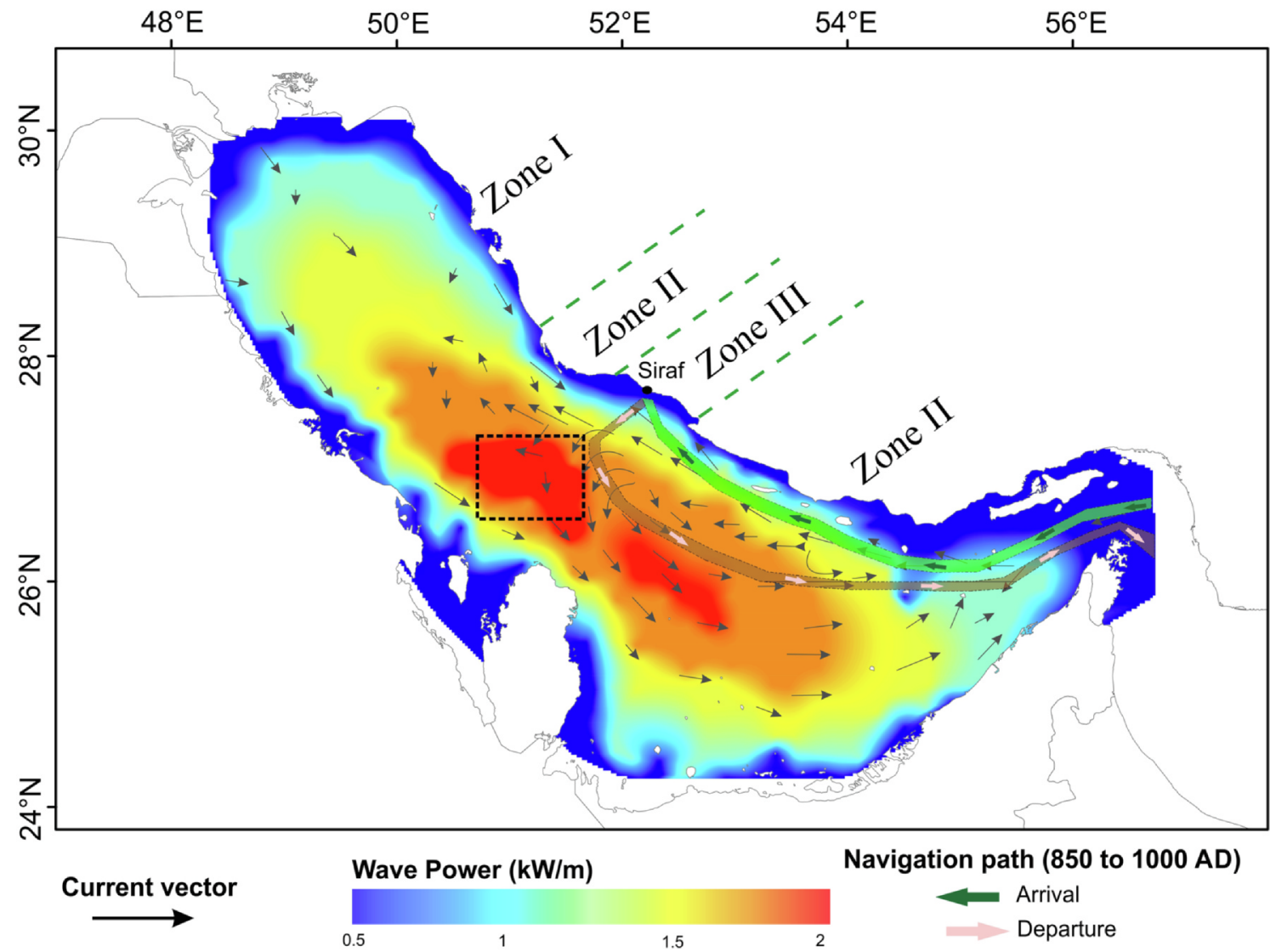

Fig. 5. Persian Gulf wave-power distribution (Kamranzad et al., 2013) and current directions (Thoppil and Hogan; 2010). The black dashed line shows the location of the Gulf's "Bermuda triangle" and probable ancient navigation route in the central basin.
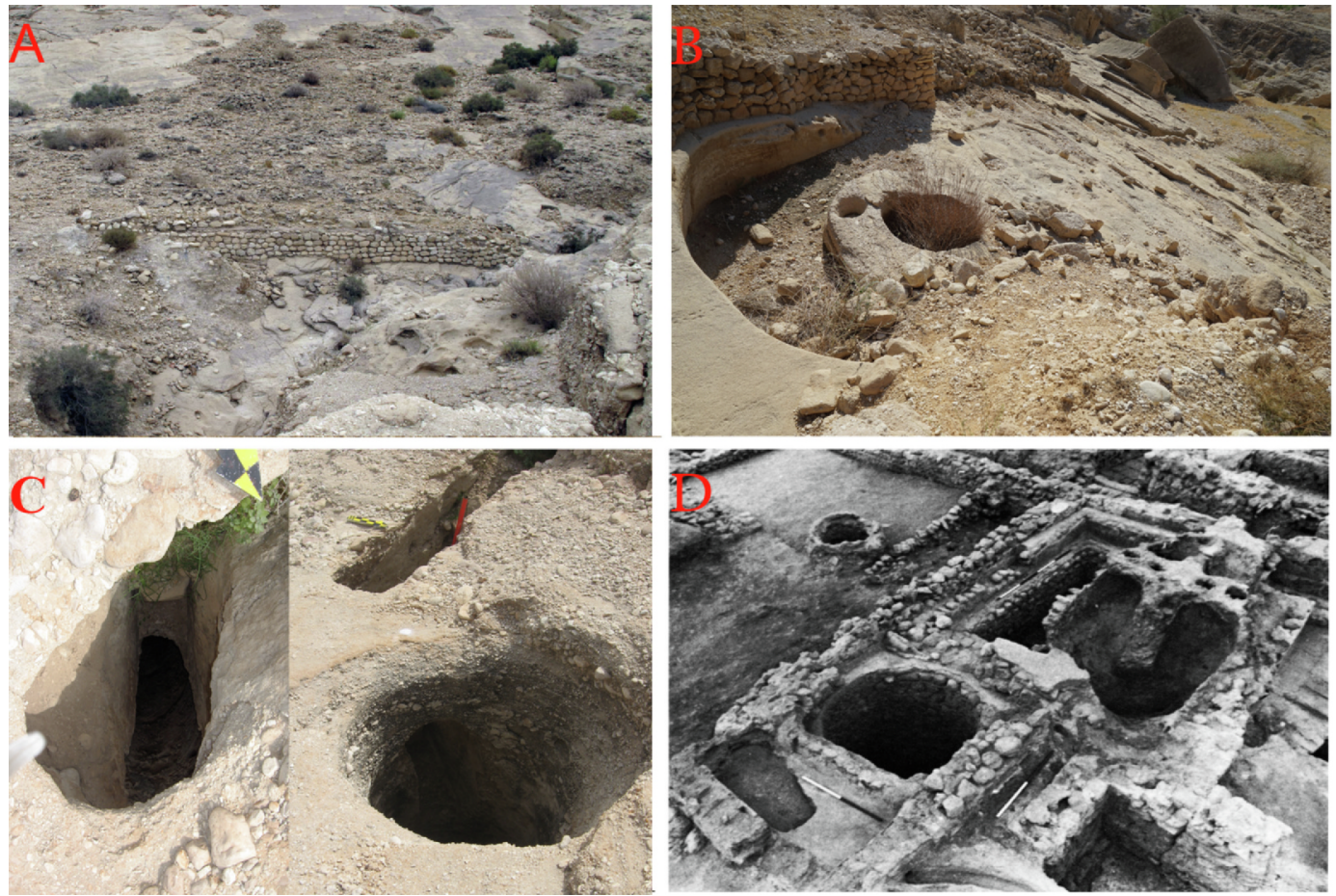

Fig. 6. A and B) plastered mortar rubble to restrict downstream debris flows and sediment influx into the excavated wells. C) Surface water channels into the wells. D) Well associated with a tank, drain and cistern (850 CE) from Whitehouse (1971). 


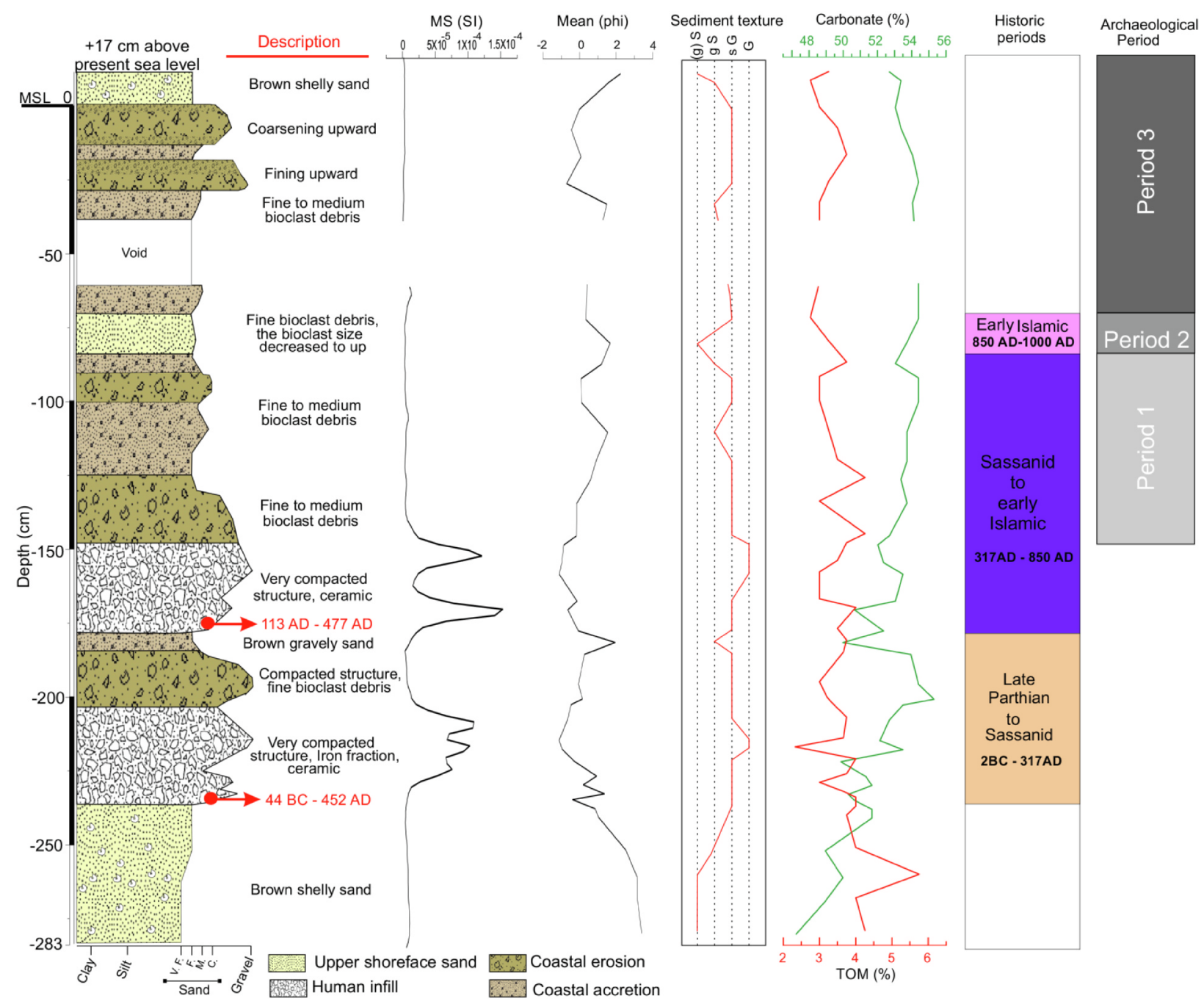

Fig. 7. Stratigraphic log of the study core with MS values, mean grain size, sediment texture, OM, carbonate content and archaeological periods (Whitehouse, 1968).

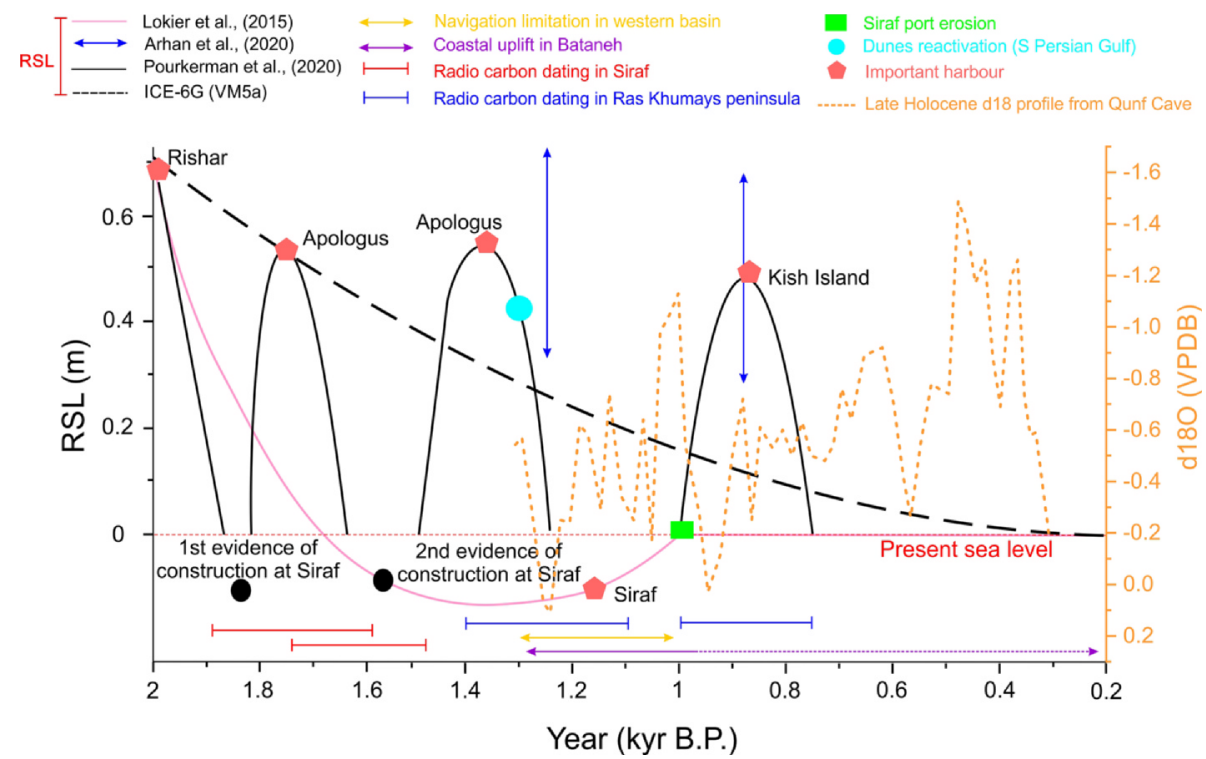

Fig. 8. The black line RSL curve in the northern part of the central basin (Pourkerman et al., 2020). The pink line denotes the reconstructed RSL for the United Arab Emirates (UAE) (Lokier et al., 2015). The blue arrow shows the RSL recorded at Ras Khumays peninsula in the UAE (Arhan et al., 2020). The dashed line indicates RSL changes evaluated by ICE-6G (VM5a) at Siraf. The dashed brown line shows late Holocene oxygen isotope records from the Arabian Peninsula (Fleitmann et al., 2003). 


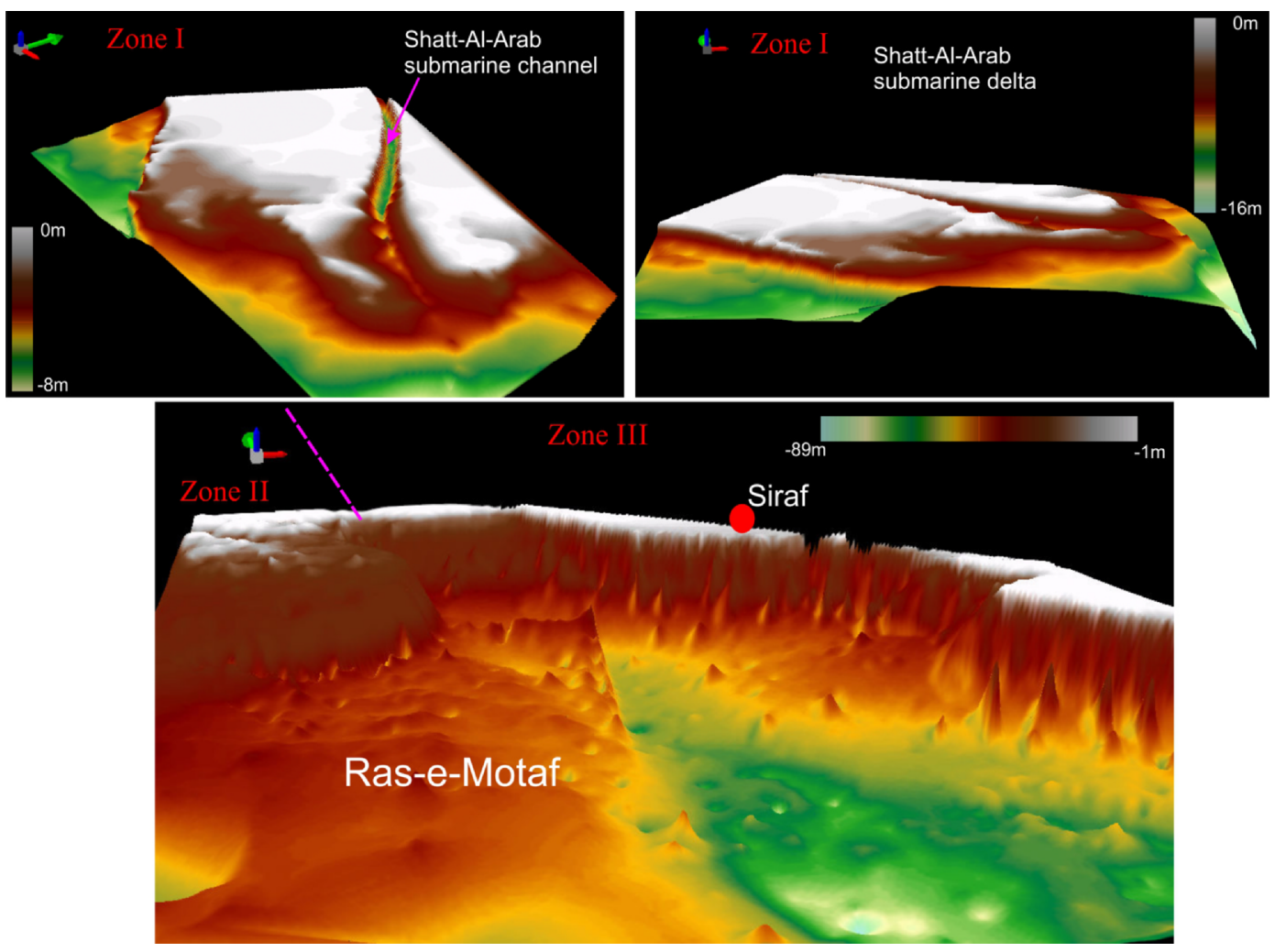

Fig. 9. 3D model of Shatt-al-Arab submarine river delta and Siraf coastal morphology.

dynasty in $750 \mathrm{CE}$ was associated with the introduction of Islamic maritime trade. By that time, RSL was at a lowstand and the Shatt-alArab river channel had prograded into the sea over its palaeo-delta. The delta was prograding by fluvial and tidal processes. It had negligible impacts on the pro-delta that was below low-tide level. A small and shallow tidal channel developed at the delta front. As a result, the navigable water column became too shallow during low-tide in the Shattal-Arab estuary. This acted as an obstacle for ocean-going vessels to enter and navigate the Shatt-al-Arab river channel. As a result, oceangoing vessels were no longer able to use the harbours at Shatt-al-Arab and in zone I (Figs. 9 and 1).

"In this deadly sea (Persian Gulf) several dangerous routes exist and the toughest one is Jannaba (Bandar-e Ganaveh) to Basra, the so-called Hor-e Jannaba, which is a terrible place during storms. Also, there is a place called Kheshbat at 6 meel (distance unit) from Abadan on the sea, along the Tigris river. In some cases the water is so shallow that big ships cannot enter, even at high tide. Several towers have been erected in order to guide the ships to the Tigris estuary using fire light at night. Those ships that deviate from the path run aground in shallow water" (Ibn Hawqal, 1965)

These environmental changes led to a shift in the location of the most important harbours from the west (zone I) to the central basin (zone III) of the Persian Gulf (Apologus to Siraf). During the latter half of the ninth century, the harbours of Apologus and Basra went into decline at the same time as Siraf grew in importance (Ricks, 1970). Siraf became a key maritime port due to the location of the site (close to Rase-Motaf), relative coastal stability with low vertical movements and a steep coastal morphology (Fig. 9).

Southward migration of the monsoon between $750 \mathrm{BCE}$ to $650 \mathrm{CE}$ led to an interruption of precipitation in northern Oman (Fleitmann and Matter, 2009) and decreasing summer Shamal wind intensity. Northwest harbours were more accessible for merchants through Ras-eMotaf. The monsoon resumed after $650 \mathrm{CE}$, coincident with an intensification of summer Shamal winds (Fig. 8). Around this time, there is evidence of dune reactivation in the south of the Persian Gulf (Stokes et al., 2003; Parker and Goudie, 2008).
Navigation risks in the western part of the Persian Gulf increased during summer months by the interaction of Persian Gulf water circulation and summer Shamal winds at Ras-e-Motaf. The most significant impact of the summer Shamal wind was on Ras-e-Motaf. Ras-e-Motaf lies on the border between the central and the western basins (zone III). Due to its unique morphology, the highest wave energy in the Persian Gulf is created in this area during storm conditions (Kamranzad et al., 2013). Therefore, navigating through the Ras-e-Motaf was dangerous for sea-going vessels, and damage/sinking was not uncommon.

A RSL rise after $950 \mathrm{CE}$, and increasing monsoon activities, led to significant erosion of the Siraf structures in the coastal zone and maritime trade shifted to Kish Island (Figs. 7 and 8). The most important barrier to rekindling prosperity in western ports such as Siraf was seafaring conditions. Ocean-going vessels accessed the Persian Gulf via the Strait of Hormuz when the counter wind and swell was minimum.

During the dry season, particularly in August, the impacts of the summer-time Shamal wind on the central basin was minimum. Furthermore, the $S$ winds and the NNE to NE surface current directions were favorable to seafaring in the central basin.

Inaccessibility of the western basin's ports eventually led to them being superseded by ports in the central basin. Furthermore, the wintertime Shamal wind began in October with minimum intensity. WNW winds, with southeastward surface currents, allowed vessels to travel from the Persian Gulf into the Indian Ocean. As a result, Siraf provided the best alternative roadstead for Persian and Arabian harbours in the western basin.

\subsection{Advantages of Siraf as an important harbour}

The falling RSL provided Siraf with suitable conditions for seafarers to access both the hinterland and the sea. The advantage of Siraf was: (i) its unique coastal morphology; (ii) its location in the Gulf (the nearest possible place to Ras-e-Motaf); and (iii) its close ties with the hinterland. The harbour of Siraf is located in zone III. Its connection to the deep water was possible via its steep coastal morphology (Fig. 9). 


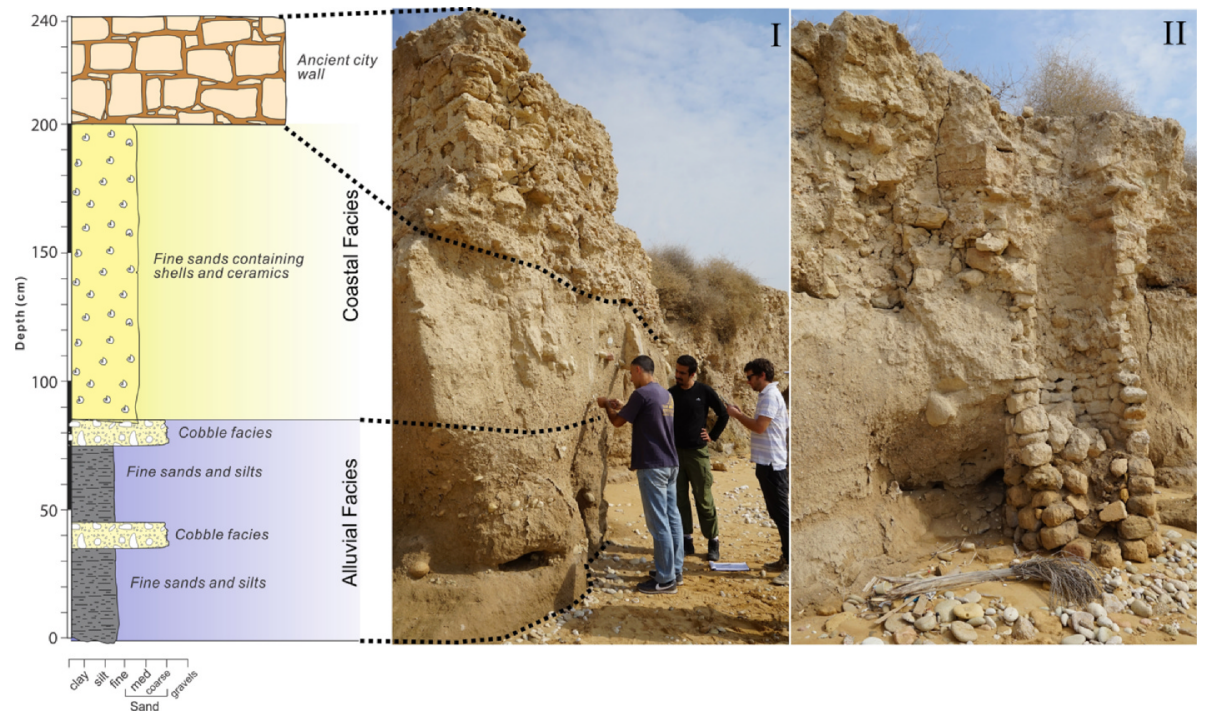

Fig. 10. Stratigraphic section of the ancient wall in the Potter's Quarter, I) A: natural deposits and B: Ancient wall II) Cross section of the well.

The close proximity of Siraf to Firuzabad made Siraf's port facilities particularly attractive to seafarers and merchants. The city's initial military vocation (Lowick, 1985) was gradually superseded by a commercial raison d'être and Siraf became one of the main trade cities of the Persian Gulf. Concurrent with the decline of the port of Apologus around $750 \mathrm{CE}$, the first evidence of trade with China is observed at Siraf (Whitehouse, 2009; Pashazanous et al., 2014). Underwater surveys have demonstrated that the city extended at least $300 \mathrm{~m}$ from the present shoreline (Khakzad et al., 2015). This suggests that falling RSL and positive coastal sediment budgets allowed the medieval city to extend seawards.

According to the stratigraphic section and Whitehouse (1968) the city is erected atop coastal sandy sediments with shell fractions. The facies constituted a permeable basement for the transfer of fresh water. A modified Qanat system was designed for collecting and transferring freshwater to the city. The technique was adapted to Siraf's geomorphological context, characterized by saline seawater levels to the south and the hills to the north. The Qanat system comprised a series of wells dug into alluvial sediments beneath the groundwater level in foothills and water flow by gravity via a network of gently sloping tunnels that transported water to lower elevations (Beaumont, 1971). At Siraf, the wells were dug into the sandstone with interlayers of conglomerates on the steeper hillside slopes. The wells were interconnected via underground tunnels and/or permeable layers.

The exposed coastal section of medieval Siraf, shows interlayers of fine sand with pebbles that translate flooding (Fig. 10). To alleviate flood damage but harness water for consumption during the wet seasons, the local watershed was extensively modified. Several variouslysized dams, sandstone carving and plastered rubble were used to alleviate water energy and trap water on the hillside. Water was collected in numerous wells behind the dams. Nonetheless, these hillside wells were not sufficient in meeting the needs of all domestic and agricultural activities. Whitehouse (1968) has suggested that other wells and cisterns were used to tap underground water resources.

Collected water was discharged downstream and transported to the irrigation system or stored underground in wells and cisterns. The different densities between the saline sea water and fresh water created a mixing zone (Back et al., 1986) that ensured that fresh water did not flow into the sea. Furthermore, the unique geomorphology of Siraf, with a small and flat tidal area, reduced the mixing zone (Pourkerman et al., 2018). Therefore, the city possessed a sustainable fresh-water resource, in the form of shallow wells (above sea level), for domestic and agriculture purposes (Fig. 10).

\subsection{The decline of Siraf}

In the eleventh century, the great port of Siraf went into decline and Kish Island replaced it for maritime trade (Whitehouse, 1983). Al-Muqaddasi reported that the $977 \mathrm{CE}$ earthquake significantly damaged Siraf. According to archaeological excavations and the voyage descriptions of $\mathrm{Ya}^{-} \mathrm{qu}^{-} \mathrm{t}$, medieval Siraf was used until the 13th century CE (al-Muqaddasi, 1906, Whitehouse and Williamson, 1973; $\mathrm{Ya}^{-} \mathrm{qu}^{-} \mathrm{t}$, 1955, Whitehouse, 2009; Pashazanous et al., 2014). Environmental factors such as RSL and climate changes probably contributed to the gradual demise of Siraf.

In Abu Dhabi, RSL reached the present level after 1.17 kyr B.P. (Lokier et al., 2015). A highstand is recorded between 950 and $1230 \mathrm{CE}$ (Arhan et al., 2020) that it is correlated with the US2 marine facies. Rising RSL and increasing summer Shamal wind intensity (Fig. 8) accentuated erosion of Siraf's port. The coastal stratigraphy shows two erosional facies over the anthropogenic horizons that clearly underline the impacts of marine currents on anthropogenic facies.

The Shamal winds, which played an important role in developing maritime trade at Siraf, turned into a hazard during the ensuing phase of RSL rise. The foundations of medieval Siraf were sensitive to erosion. Erosion removed the lower compact sediments leading to the collapse of overlying infrastructure. Due to the absence of robust construction materials, coastal processes easily eroded gypsum between the plastered rubble. Therefore, the structures were easily degraded and the sediment fractions reworked by coastal processes and longshore currents. This could explain why there are no reports of preserved underwater structures in Siraf. Furthermore, RSL rise significantly compromised the city's water resources. RSL rise, led to salt-water intrusion into wells. Access to fresh water in the city therefore became limited. In light of the environmental impacts on civil and trade infrastructure, Siraf's population gradually migrated away from the city.

Due to changing coastal processes, erosion took place with the reworking of finer sediment stocks. Erosional facies between the accretion layers suggest a fall in sediment supply during RSL rise or an increase in environmental energy resulting from storm events during an intensification of monsoon events between 1600 and 1500 CE (Fig. 8). In both cases, coarse sediment derives from the erosion of waterfront anthropogenic remains. Erosion of the coastal archaeology is clearly attested along the present shoreline (Pourkerman et al., 2018). 


\section{Conclusion}

Maritime trade in the Persian Gulf was very important for Sassanian and Islamic dynasties, who prioritized the best locations for commercial ports. Several archeological studies have been undertaken on medieval Siraf and other ports of the Persian Gulf. However, numerous questions remain unanswered. In conclusion, we would like to insist on the following factors to explain the evolution of medieval Siraf.

Early evidence of human settlement in Siraf dates back to early Sassanid and possibly late Parthian periods.

Siraf became important for Persian Gulf maritime trade because other important ports (e.g. Apologus, Bushehr, Mahruban) located in the western basin could not be used by ocean-going vessels. Climate change, RSL fall, coastal morphology and the Shamal winds were keys factors in the rise in importance of Siraf for maritime trade. The ports located in Shatt-al-Arab and the western Persian Gulf lost their significance when RSL in the Gulf reached a lowstand after $1.4 \mathrm{kyr}$ B.P. and a more vigorous summer-time Shamal disconnected the western and central basins of the Persian Gulf. The fresh water-management system of Siraf was unique and cleverly adapted to the local geomorphology. Its design was based on the local environment, and its lithological and sedimentological properties. It was a modified version of the Qanat system, adapted to the coastal environment. In addition to meeting the fresh-water demands of the city, it also alleviated the impact of flooding events from the northern hills.

The decline of medieval Siraf partially resulted from RSL rise and winter-time Shamal winds that eroded waterfront infrastructure and degraded harbour amenities.

Seafarers exploited the Shamal winds for sailing in the Persian Gulf. August and October were the best times for the arrival and departure of ocean-going vessels in the central basin, respectively. The RSL results show that sea level rose from its lowstand position to present levels between 1.1 and $1 \mathrm{kyr}$ BP.

During the last two last decades, concurrent with oil-gas industry developments in the coastal zone, several archaeological sites have been destroyed due to industrial constructions and urbanization. A number of heritage remains have already been lost and others are at risk. This study has revealed the importance of geoarchaeological studies in understanding the environmental evolution of ancient maritime sites of the Persian Gulf.

\section{CRediT authorship contribution statement}

Majid Pourkerman: Conceptualization, Data curation, Formal analysis, Investigation, Methodology, Project administration, Software, Validation, Visualization, Writing - original draft, Writing - review \& editing. Nick Marriner: Validation, Writing - review \& editing. Christophe Morhange: Supervision, Validation, Writing - review \& editing. Morteza Djamali: Funding acquisition, Supervision, Validation, Writing - review \& editing. Giorgio Spada: Data curation, Formal analysis, Methodology, Software, Validation, Writing - review \& editing. Sedighe Amjadi: Validation, Writing - review \& editing. Matteo Vacchi: Validation, Writing - review \& editing. Hamid Lahijani: Funding acquisition, Validation, Writing - review \& editing. Mohammad Esmaeili Jelodar: Resources, Validation, Writing - review \& editing. Hossein Tofighian: Resources, Writing - review \& editing. Abdolmajid Naderi Beni: Funding acquisition, Resources, Writing review \& editing.

\section{Acknowledgements}

This work was supported by the Center of International Scientific Studies and Collaborations (CISSC), Iran National Science Foundation
(INSF grant number 94-44915), the French Embassy in Iran, Campus France (PHC GUNDISHAPUR 2016-2017, project number 35630QH) and Labex OT-Med (ANR-11-LABX-0061). Radiocarbon datings were funded through the project "LIA HAOMA" supported by the Centre National de Recherche Scientifique (CNRS, France). The study was also supported by Iran's National Elite Foundation.

\section{References}

Al Senafi, F., Anis, A., 2015. Shamals and climate variability in the Northern Arabian Persian Gulf from 1973 to 2012. Int. J. Climatol. 35 (15), 4509-4528.

Alavi, M., 1994. Tectonics of the Zagros orogenic belt of Iran: new data and interpretations. Tectonophysics 229 (3-4), 211-238.

Alavi, M., 2004. Regional stratigraphy of the Zagros fold-thrust belt of Iran and its proforeland evolution. Am. J. Sci. 304 (1), 1-20.

Al-Istakhri, (1870), M. J. de Goeje (trans. \& ed.), Kitab Al-Masalik wa-al-Mamalik. Leiden. al-Mas'udi, A. L. H. (1962). Les prairies d'or. Trans. C. Barbier de Meynard, Pavet de Courteille, and Charles Pellat. Paris: Société asiatique.

Al-Muqaddasi,, 1906. Ahsan al-Taqasim fi Ma'rifat al-Aqalim. Bibliotheca Georaphorum Arabicorum, Leiden.

Arhan, D., Pavlopoulos, K., Fouache, E., 2020. Holocene relative sea-level variations and archeological implications, Abu Dhabi western region, United Arab Emirates. Arab. J. Geosci. 13 (6), 1-16.

Arian, M., Noroozpour, H., 2015. Tectonic geomorphology of Iran's salt structures. Open J. Geol. 5 (02), 61.

Back, W., Hanshaw, B.B., Herman, J.S., Van Driel, J.N., 1986. Differential dissolution of a Pleistocene reef in the ground-water mixing zone of coastal Yucatan Mexico. Geology 14 (2), 137-140.

Bartlett, K.S., 2004. Dust Storm Forecasting For Al Udeid Ab, Qatar: An Empirical Analysis. Master's thesis. Air University, Islamabad.

Beaumont, P., 1971. Qanat systems in Iran. Hydrol. Sci. J. 16 (1), 39-50.

Caspers, E.C.D., 1971. New archaeological evidence for maritime trade in the Persian Gulf during the Late Protoliterate period. East West 21 (1/2), 21-44.

Crook, J. (2009). Climate analysis and long range forecasting of dust storms in Iraq. Naval Postgraduate School Monterey CA.

Defant, A., 1961. Physical Oceanography 1, Pergamon.

Delile, H., Mazzini, I., Blichert-Toft, J., Goiran, J.P., Arnaud-Godet, F., Salomon, F., Albarède, F., 2014. Geochemical investigation of a sediment core from the Trajan basin at Portus, the harbour of ancient Rome. Ouat. Sci. Rev. 87, 34-45.

Djamali, M., Akhani, H., Andrieu-Ponel, V., Braconnot, P., Brewer, S., de Beaulieu, J.-L., Fleitmann, D., Fleury, J., Gasse, F., Guibal, F., Jackson, S.T., Lézine, A.-M., Médail, F., Ponel, P., Roberts, N., Stevens, L., 2010. Indian Summer Monsoon variations could have affected the early-Holocene woodland expansion in the Near East. Holocene 20, $813-820$.

Ferrario, M.F., Brunamonte, F., Caccia, A., Livio, F., Martinelli, E., Mazzola, E., Michetti, A.M., Terrana, S., 2015. Buried landscapes: Geoarchaeology of the roman harbour of Como (N Italy). Alp. Mediterr. Quat 28 (2).

Flaux, C., Marriner, N., el-Assal, M., Kaniewski, D., Morhange, C., 2017. Late Holocene erosion of the Canopic promontory (Nile Delta, Egypt). Marine Geol. 385, 56-67.

Fleitmann, D., Matter, A., 2009. The speleothem record of climate variability in Southern Arabia. Comptes Rendus Geosci. 341 (8-9), 633-642.

Fleitmann, D., Burns, S.J., Mudelsee, M., Neff, U., Kramers, J., Mangini, A., Matter, A., 2003. Holocene Forcing of the Indian Monsoon Recorded in a Stalagmite from Southern Oman. Science 5626, 1737-1739.

Folk, R.L., 1980. Petrology of Sedimentary Rocks. Hemphill Publishing Company.

Folk, R.L., Ward, W.C., 1957. Brazos River bar [Texas]; a study in the significance of grain size parameters. J. Sedim. Res. 27 (1), 3-26.

Folk, R.L., 1954. The distinction between grain size and mineral composition in sedimentary rock nomenclature. J. Geol. 62 (4), 344-359.

Giannakopoulou, E.M., Toumi, R., 2012. The Persian Gulf summertime low-level jet over sloping terrain. Quart. J. Royal Meteorol. Soc. 138 (662), 145-157.

Goiran, J.P., Salomon, F., Mazzini, I., Bravard, J.P., Pleuger, E., Vittori, C., Boetto, G., Christiansen, J., Arnaud, P., Pellegrino, A., Pepe, C., 2014. Geoarchaeology confirms location of the ancient harbour basin of Ostia (Italy). J. Archaeol. Sci. 41, 389-398.

Heiri, O., Lotter, A.F., Lemcke, G., 2001. Loss on ignition as a method for estimating organic and carbonate content in sediments: reproducibility and comparability of results. J. Paleolimnol. 25, 101-110. https://doi.org/10.1023/A:1008119611481.

Huff, D., 1986. Architecture: III: Sasanian period. Encyclopedia Iranica 2, 329-334.

Ibn Hawqal, (1965), J. H. Kramers (trans. \& ed.), Kitab Surat al-Ard. Bibliotheca Georaphorum Arabicorum, Leiden.

Jahani, S., Callot, J.P., de Lamotte, D.F., Letouzey, J., Leturmy, P., 2007. The salt diapirs of the eastern Fars Province (Zagros, Iran): A brief outline of their past and present. In: Thrust Belts and Foreland Basins. Springer, Berlin, Heidelberg, pp. 289-308.

Kamranzad, B., 2018. Persian Gulf zone classification based on the wind and wave climate variability. Ocean Eng. 169, 604-635.

Kamranzad, B., Etemad-Shahidi, A., Chegini, V., 2013. Assessment of wave energy var iation in the Persian Gulf. Ocean Eng. 70, 72-80.

Kashfi, M.S., 1976. Plate tectonics and structural evolution of the Zagros geosyncline, southwestern Iran. Geol. Soc. Am. Bullet. 87 (10), 1486-1490.

Khakzad, S., Trakadas, A., 2014. The world in a grain of sand: Siraf. In: Sindbæk, S., Trakadas, A. (Eds.), The World in the Viking Age, 108-110. Roskilde.

Khakzad, S., Trakadas, A., Harpster, M., Wittig, N., 2015. Maritime Aspects of Medieval Siraf, Iran: a pilot project for the investigation of coastal and underwater 
archaeological remains. Int. J. Nautical Archaeol. 44, 258-276.

Lambeck, K., 1996. Shoreline reconstructions for the Persian Gulf since the last glacial maximum. Earth Planet. Sci. Lett. 142 (1-2), 43-57.

Le Strange, G., 1905. The lands of the Eastern caliphate: Mesopotamia, Persia, and central Asia, from the Moslem conquest to the time of Timur Vol. 4 CUP Archive.

Lisle, T.E., 1989. Sediment transport and resulting deposition in spawning gravels, north coastal California. Water Resour. Res. 25 (6), 1303-1319.

Lokier, S.W., Bateman, M.D., Larkin, N.R., Rye, P., Stewart, J.R., 2015. Late Quaternary sea-level changes of the Persian Gulf. Quarter. Res. 84 (1), 69-81.

Lowick, N.M., 1985. The Coins and Monumental Inscriptions, Siraf XV. British Institute of Persian Studies, London, pp. 11-16.

Marriner, N., Morhange, C., 2007. Geoscience of ancient Mediterranean harbours. EarthSci. Rev. 80 (3-4), 137-194.

Marriner, N., Flaux, C., Morhange, C., Stanley, J.-D., 2013. Tracking Nile Delta vulnerability to Holocene change. PLoS One 8 (7), e69195.

Marriner, N., Morhange, C., Doumet-Serhal, C., 2006. Geoarchaeology of Sidon's ancient harbours, Phoenicia. J. Archaeol. Sci. 33 (11), 1514-1535.

Marriner, N., Morhange, C., Goiran, J.P., 2010. Coastal and ancient harbour geoarchaeology. Geol. Today 26 (1), 21-27.

Marriner, N., Morhange, C., Boudagher-Fadel, M., Bourcier, M., Carbonel, P., 2005. Geoarchaeology of Tyre's ancient northern harbour, Phoenicia. J. Archaeol. Sci. 32, 1302-1327.

Marriner, N., Morhange, C., Flaux, C., Carayon, N., 2017. Harbours and ports. Encyclopedia Geoarchaeol. 382-403.

Morhange, C., Marriner, N., 2010. Mind the (stratigraphic) gap: Roman dredging in an cient Mediterranean harbours. Bollettino di Archeologia on line 23-32.

Parker, A.G., Goudie, A.S., 2008. Geomorphological and palaeoenvironmental investigations in the southeastern Arabian Gulf region and the implication for the archaeology of the region. Geomorphology 101, 458-470.

Pashazanous, H.R., Montazer Zohouri, M., Ahmadi, T., 2014. Sea trade between Iran and China in the Persian Gulf based on the excavations of Sīräf city. Indian J. Econ. Develop. 2, 6-13.

Peltier, W.R., Argus, D.F., Drummond, R., 2015. Space geodesy constrains ice age terminal deglaciation: The global ICE-6G_C (VM5a) model. J. Geophys. Res.: Solid Earth 120 (1), 450-487.

Peltier, W.R., Argus, D., Drummond, R., Moore, A.W., 2012. Postglacial rebound and current ice loss estimates from space geodesy: the new ICE-6G (VM5a) global model. In AGU Fall Meeting Abstracts.

T.J. Perrone Winter shamal in the Persian Gulf, Naval Env Prediction Res. Facility, Technical Report 79-06 1979 Monterey, 180 pp.

Potter, L., 2009. The Persian Gulf in History. Springer.

Pourkerman, M., Marriner, N., Morhange, C., Djamali, M., Amjadi, S., Lahijani, H., ShahHoesseini, M., 2018. Tracking shoreline erosion of "at risk" coastal archaeology: The example of ancient Siraf (Iran, Persian Gulf). Appl. Geogr. 101, 45-55.

Pourkerman, M., Marriner, N., Morhange, C., Djamali, M., Lahijani, H., Amjadi, S.,... \& Naderi, M., 2020. Late Holocene relative sea-level fluctuations and coastal uplift in the Persian Gulf: implications for Bataneh (Najirum) archaeological site. Unpublished paper, Iran.
Pous, S., Carton, X. J., \& Lazure, P. (2012). A process study of the tidal circulation in the Persian Gulf.

Purser, B.H., Seibold, E., 1973. The principal environmental factors influencing Holocene sedimentation and diagenesis in the Persian Gulf. In: The Persian Gulf. Springer, Berlin, Heidelberg, pp. 1-9.

Reynolds, R.M., 1993. Physical oceanography of the Gulf, Strait of Hormuz, and the Gulf of Oman-Results from the Mt Mitchell expedition. Marine Pollut. Bullet. 27, 35-59.

Ricks, T.M., 1970. Persian Gulf seafaring and East Africa: Ninth-twelfth centuries. Afr. Historical Stud. 339-357.

Seibold, E., Vollbrecht, K., 1969. Die bodengestalt des persischen golfs. "Meteor" forschungsergebnisse. Reihe C 2, 29-56.

Sharland, P.R., Casey, D.M., Davies, R.B., Simmons, M.D., Sutcliffe, O.E., 2004. Arabian plate sequence stratigraphy-revisions to SP2. GeoArabia 9 (1), 199-214.

Sheriff, A., 1987. Slaves, spices and ivory in Zanzibar: Integration of an East African commercial empire into the world economy. Ohio University Press, pp. 1770-1873.

Southon, J., Kashgarian, M., Fontugne, M., Metivier, B., Yim, W.W., 2002. Marine reservoir corrections for the Indian Ocean and Southeast Asia. Radiocarbon 44 (1), $167-180$.

Spada, G., Melini, D., 2019. SELEN4 (SELEN version 4.0): a Fortran program for solving the gravitationally and topographically self-consistent Sea Level Equation in Glacial Isostatic Adjustment modeling. Geoscientific Model Develop. 12 (12), 5055-5075.

Stiffe, A.W., 1895. Ancient Trading Centres of the Persian Gulf: I Siráf. Geogr. J. 166-173.

Stokes, S., Goudie, A.S., Colls, A.E.L., Al-Farraj, A., 2003. Optical dating as a tool for studying dune reactivation, accretion rates and desertification over decadal, centennial and millennial timescales. Desertification in the Third Millenium. Balkema, Rotterdam, pp. 57166.

Tabari,, 1987. The History of al-Tabari, vol 1 State University of New York, Albany.

Thoppil, P.G., Hogan, P.J., 2010. Persian Gulf response to a wintertime shamal wind event. Deep Sea Research Part I: Oceanographic Research Papers 57 (8), 946-955.

Vacchi, M., Ermolli, E.R., Morhange, C., Ruello, M.R., Di Donato, V., Di Vito, M.A., Giampaola, D., Carsana, V., Liuzza, V., Cinque, A., Boetto, G., 2020. Millennial variability of rates of sea-level rise in the ancient harbour of Naples (Italy, western Mediterranean Sea). Quaternary Res. 93 (1), 284-298.

Vosougi, M.B., Sefatgo, M., 2016. The historic atlas of ports and marine navigation in Iran. Ports and Maritime Organization [Farsi].

Whitehouse, D., 1983. Maritime trade in the Gulf: The 11th and 12th centuries. World Archaeol. 14 (3), 328-334.

Whitehouse, D., Williamson, A., 1973. Sasanian maritime trade. Iran 11 (1), 29-49.

Whitehouse, D., 1968. Excavations at Siraf: First Interim Report. Iran 6, 1-22.

Whitehouse, D., 1969. Excavations at Siraf: Second Interim Report. Iran 7, 39-62.

Whitehouse, D., 1970. Excavations at Siraf: Third Interim Report. Iran 8, 1-18.

Whitehouse, D., 1971. Excavations at Siraf: Fourth Interim Report. Iran 9, 1-17.

Whitehouse, D., 2009. Siraf, History. Topography and Environment, Oxford.

Wilkinson, T.J., 1974. Agricultural decline in the Siraf region. Iran. Paléorient 123-132.

Wood, W.W., Bailey, R.M., Hampton, B.A., Kraemer, T.F., Lu, Z., Clark, D.W., James, R.H., Al Ramadan, K., 2012. Rapid late Pleistocene/Holocene uplift and coastal evolution of the southern Arabian (Persian) Gulf. Quaternary Res. 77 (2), 215-220.

Yaqut, 1955-57, Mu’jam al-Buldan. Beirut. 